\title{
Dublin House Prices: A History of Booms and Busts from 1708-1949
}

\author{
Karl Deeter \\ Irish Mortgage Brokers \\ Frank Quinn \\ Property Industry Ireland \\ David Duffy \\ Blackrock Further Education Institute \\ (read before the Society, 15 October 2015)
}

\begin{abstract}
This paper presents an annual property price index for Dublin over the period 1708-1949. Obtaining the data for a historical index and presenting it was the objective of this research. It was done in the belief that any better insight into property prices via a long range price index would help in delivering more accurate historical facts as they relate to housing. Data for the index was researched from examination of actual property transactions recorded in the Registry of deeds. The index is constructed using the Hedonic method and is estimated in real and nominal terms.
\end{abstract}

Keywords: economic history, house prices, Dublin

JELs: N13, N14, N93, N94

\section{INTRODUCTION}

In the aftermath of the $21^{\text {st }}$ century Irish financial crisis there has been renewed interest in property as an asset class, particularly in how it interacted with the general economic cycle. The absence of a historical Irish house price index means we have no knowledge of the details of Irish property cycles, their shape, duration, or of how calamitous events such as the Great Famine, Civil War or subsequent Independence and Central Bank formation affected house prices other than through historical accounts which are often founded on scant detail, and commentary rather than data.

Property is the largest investment most of us will make in our lifetimes and our greatest store of wealth or debt. The price an individual can pay for a property is linked to their salary, job status, credit rating and even their age, marital status and number of children. Property values themselves are determined by Income levels, Population changes, Rate of Unemployment, Interest rates and the availability of credit. Therefore a study of historical property prices is an examination of the wider economy and should help us in our understanding of the history of Irish society.

Research on the Irish housing market over the long run is, as far as we are aware, limited. O'Rourke and Polak (1991) looked at transaction volumes in Ireland on an annual basis between 1708 and 1988. More recently, Lyons (2015) presents house prices in Dublin from 1900. While transactions can imply economic activity, the lack of price matched with activity figures means part of the puzzle was missing. The absence of a price index means we have no knowledge of the details of Irish property cycles, their shape, duration, or of how calamitous events such as the Great Famine, Civil War or subsequent Independence and Central Bank formation affected house prices other than through historical accounts which are often founded on scant detail and commentary rather than data.

This paper presents an index tracking Irish house prices over the very long run. Obtaining the data and presenting it was the objective of this research. It was done in the belief that any better insight into property prices via a long range price index would help in delivering more accurate historical facts as they relate to housing, and lend itself to better current decisions in housing policy as we can look at previous outcomes. This index is representative of house prices in Dublin between the years 1708 and 1949 and was created using a mixture of hedonic and repeat sales methods. The paper is set out as follows. In section 2 we review some of the literature that has examined house prices in the long-run. Next we provide an overview of the data and the issues faced in collating it. Section 4 outlines the methodology used to construct the measure of house prices, drawing on similar international research. Section 5 discusses the results. Section 6 concludes. 


\section{LITERATURE}

A number of papers have constructed long run house price indices. An early paper looking at house prices in the very long run, Eicholtz (1997) outlines three methods of indices for property values, appraisal based, property share based and transaction based and identifies the Transaction based index as the most reliable type. For many countries and cities the transaction based index cannot be constructed due to the lack of recorded property transactions or the relatively new nature of the city. Dublin has both the historical property transaction records and the construction of comparable quality housing dating back to the early $18^{\text {th }}$ century to allow for the construction of a transaction based index.

Eichholtz (1997) uses transaction data from buildings on one of the canals in Amsterdam to construct an index covering 1628 to 1973 and finds that much of the increase in house prices in Amsterdam has been largely due to inflation. Bohlin (2014) calculates a price index for residential property in Göteborg, Sweden, from 1875 to 2010 and finds that a general pattern between 1875 and 1957 is that residential property prices fluctuated less than consumer prices. In common with a number of other papers the long-term increase in nominal prices since 1957 has been stronger than before and stronger than prices overall. Söderbery et al. (2014) use a similar approach to Bohlin (2014) when calculating an index for Stockholm from 1875 to 2012.

Residential property prices in Stockholm have generally reacted with a lag to downturns in the macroeconomic environment, for example with regard to the beginning of World War I and the depression of 1931. Eitrheim and Erlandsen (2004) construct annual house price indices for four Norwegian cities for the period 1819-2003 and find that the trend in nominal prices is upwards sloping over the period, with particularly strong growth in the final three decades to 2003. More recently, Knoll et al. (2014) present a comparison of long run price indices for a number of economies from 1870. They show a similar trend in most of the economies; real prices stayed relatively constant from the 19th to mid-20th century, reflecting falling transport costs resulting in higher land supply, but rose sharply in recent decades. Their analysis points to land prices as a key driver, accounting for about 80 per cent of the increase between 1950 and 2012.

In an Irish context, Lyons (2015) constructs a house price index for Dublin for the period 1900 to 2015. He finds that nominal Dublin house prices rose by a factor of over 450 over the entire period, with much of the increases occurring between 1950-1990. O'Rourke and Polak (1991) examined annual property transaction volumes from 1708-1988 and found that the volume of transactions were generally pro-cyclical.

\section{DATA}

The primary source of information came from the Registry of Deeds located in the James Gandon designed Kings Inn building at the top of Henrietta Street where property transactions were recorded from 1708. Our team ${ }^{1}$ analysed 20,252 memorials (deeds) in the Registry out of the approximately 5,000,000 held there. The deeds were usually two pages long or more, often illegible, many were written on calf-skin vellum pages and regularly without any prices mentioned.

To obtain the data we first had to determine the streets we would examine. Many streets have ceased to exist entirely over the last 300 years, others were extended, some were not yet established, and this meant finding ten streets that would be broadly 'representative' of Dublin over the entire time period. This was achieved with the help of a historian ${ }^{2}$ from the Royal Irish Academy, Dublin. The ten streets chosen were Anne Street, Britain Street, Bachelors Walk, Capel Street, Georges Street, Meath Street, Merchants Quay, Patrick Street, Ushers Quay and St. Stephens Green. (Figure 1).

The early 18th century is the earliest possible time to analyse Dublin house prices. Before then the majority of the estimated 2000 houses in Dublin were made of thatch and were of poor quality with very few surviving to this day. A change in building regulations resulting from the great London fire of 1666 and a large Dublin fire in 1660 ensured that brick and stone would be the building materials for the houses from that time on. The Dublin which exists today was planned and developed during the 18th century with some of the houses that were built at the time still in existence in modern times.

\footnotetext{
${ }^{1}$ Simon Farrell, Jack McGrath, Dave Galbraith, Sinead Toomey, Kerstin Jenkinson, Kendal Jordan, Brianna Jordan, Emma Ryan, Julie Dias, Lynda Collins, Heather McGrath, Frank Quinn and Karl Deeter.

${ }^{2} \mathrm{We}$ are grateful to Jennifer Moore (RIA) for her assistance with this.
} 
There were a total of 914 houses from the 10 streets and the search for transactions was carried out by the Townlands system examining the City of Dublin books. This enabled us to examine every registered property transaction from our chosen streets from the period 1708-1949. Unfortunately from 1950 onwards the Townlands system cannot be used and this has left us with a gap in our index from 1950-1969. Research has taken place in the Valuations Office on this time period and the results will be presented in a later paper.

By the late $19^{\text {th }}$ century, many of the houses in the study had become commercial properties or a combination of residential and commercial which would result in an increase in the value of the property increasing and this was controlled for in our methodology. The 1901 census provided a detailed description of every property in our street outlining its purpose at the time and also the number of families living in each.

Figure 1. Dublin Streets used in Index construction, highlighted in yellow

\section{Great Britain Street \\ 2. Capel Street \\ 3. Bachelors Walk \\ 4. Ushers Quay \\ 5. Merchants Quay \\ 6. Meath Street \\ 7. Patrick Street \\ 8. Georges Street \\ 9. Anne Street South 10. Stephens Green}

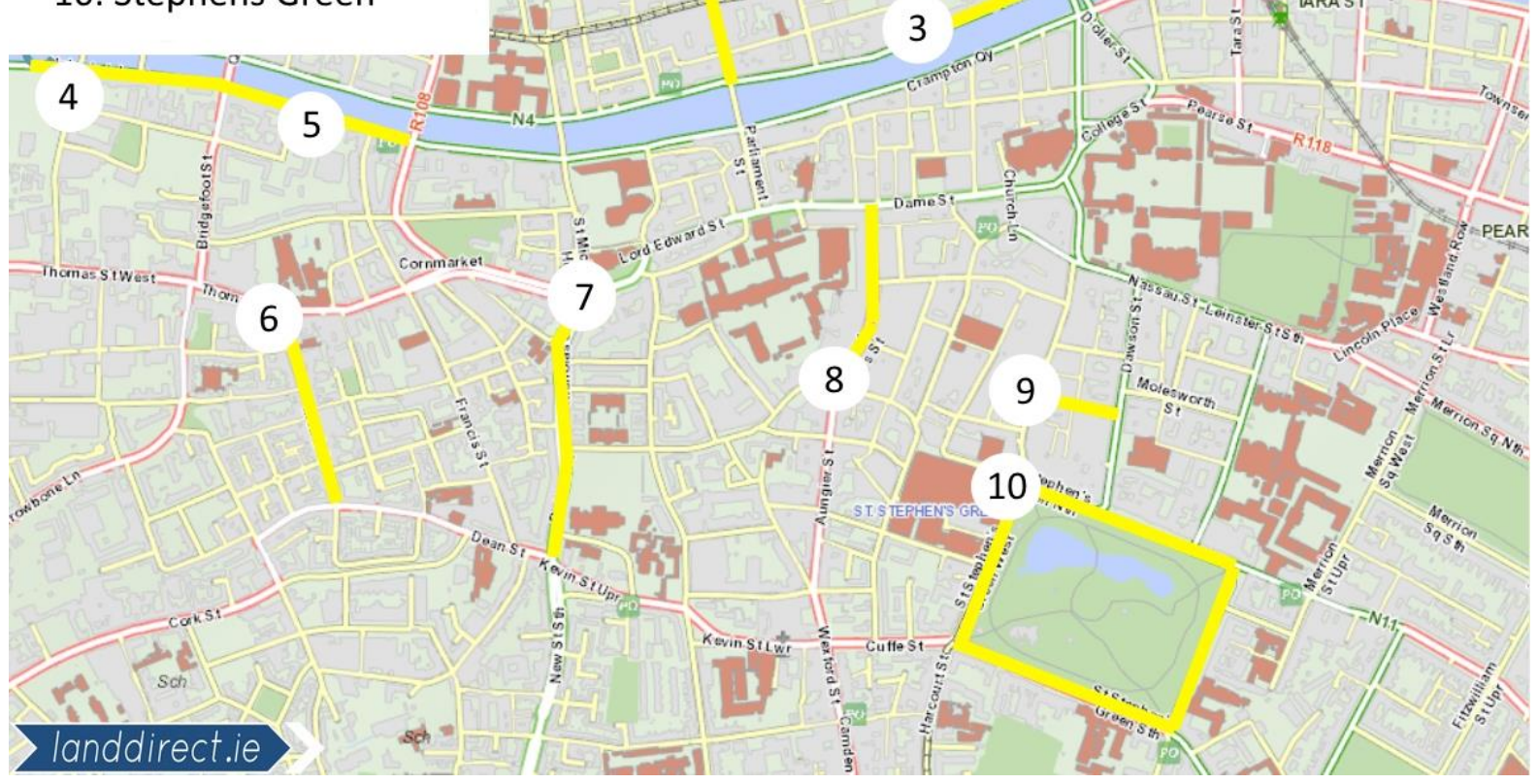

From the examination of the 20,252 property transactions, 7117 usable values were obtained to create the index. There were 2160 usable values from the period 1708-1799, 3676 values from 1800-1899 and 1335 usable values from 1900-1949. It was possible to get values for every year of the study, however the best century was the $19^{\text {th }}$ century with an average of 37 values per year, compared with 27 per year in the $20^{\text {th }}$ century and 23 per year in the $18^{\text {th }}$ century. (Figure 2).

The property values are presented in euro to allow a comparison with modern times. The vast majority of the transactions were in English pound sterling with some in the Old Irish pound. In 1701 the relationship between the Irish pound and the English pound sterling was fixed at 13 Irish pounds to 12 English pounds. In 1826 the Irish pound was abolished and replaced by the pound sterling. From 1928 to 1979, the new Irish currency (Punt) was pegged at 1:1 with sterling. 
Figure 2. Distribution of observations per year

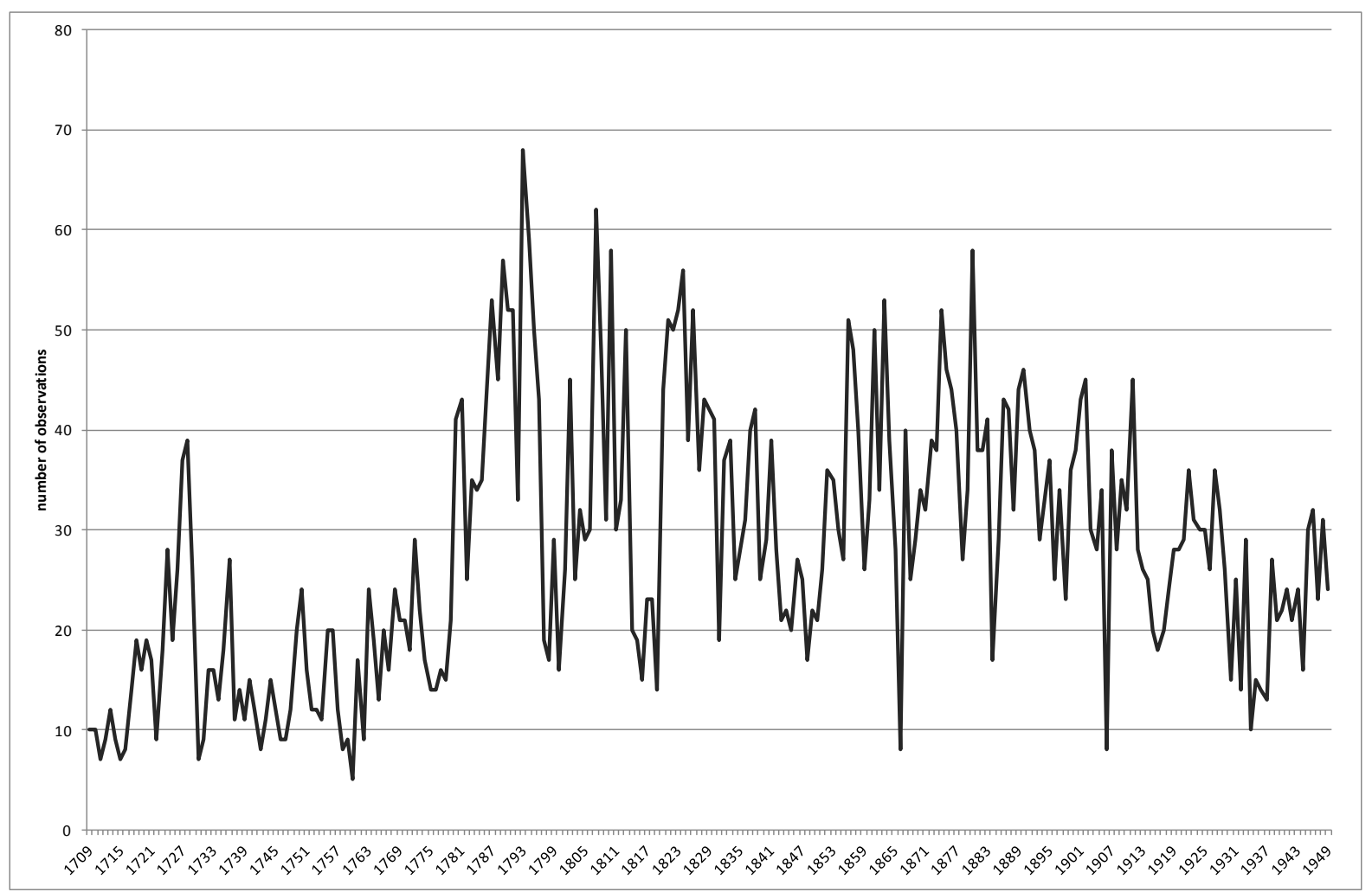

\section{METHODOLOGY}

Having collected the data as outlined in section 2, we then look to construct a measure of house prices, both nominal and real, between 1709 and 1949. In an effort to minimise the impact of outliers on the analysis we restrict our estimation to observations with plus or minus two standard deviations from the mean.

It was also important for us to use as much of the data as possible. As outlined in Section 2 data for a number of different transaction types was recorded. Where the transaction involved a Conveyance the sale price of the property was used as the property value. When the transaction recorded an annual lease value, we used a year's purchase multiplier to calculate the value of the lifetime of the lease. All leases examined were a minimum of thirty-one years. Many of the leases were for a period of ninety-nine years and in these cases, we considered leases of this type to be the lifetime of the property.

As a first step we calculate a time dummy hedonic regression. In this approach we regress house prices on dwelling characteristics and time dummies. We control for location using the street on which the property is located. However, we do not have data on the size of the properties. Given the way in which transactions are recorded, in many cases the transaction will have involved more than one property and so we control for that by creating a series of dummy variables dependent on the number of properties. In addition we control for whether or not the property had a commercial element (use).

$$
\begin{gathered}
\log P=\alpha+\beta_{1} \text { location }+\beta_{2} \text { number of properties }+\beta_{3} \text { transaction type }+\beta_{4} \text { use }+\beta_{5} \text { garden } \\
+\beta_{6} \text { garage }+\beta_{7} \text { time }
\end{gathered}
$$

In keeping with standard practise we use the mode from each set of characteristics as our reference category. An index is then constructed using the coefficients on the time dummies. ${ }^{3}$ The coefficients on the time dummy variables are used to construct our index. While the results are not reported here we also run separate regressions for each transaction types. The indices follow a similar trend but the indices for each transaction type are more volatile, reflecting smaller sample sizes.

\footnotetext{
${ }^{3}$ For a more detailed explanation see Eurostat (2013). In an Irish context see Murphy (1998), Conniffe and Duffy (1999).
} 
Figure 3: Dublin House Prices, 1709-1949, Time Dummy Hedonic, Nominal ${ }^{4}$

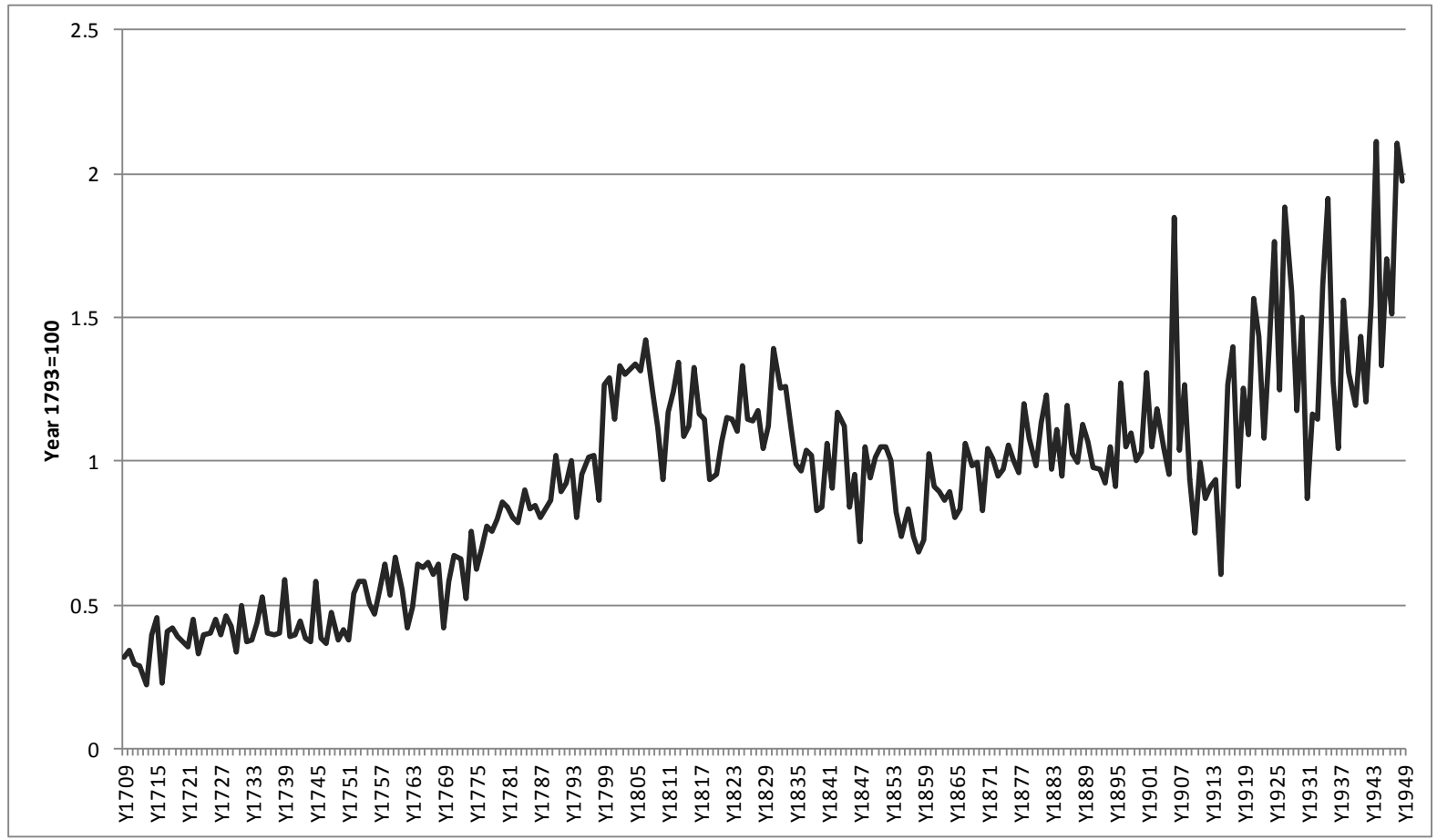

Note: regression of log price on dwelling characteristics and time dummy variables.

Number of observations $=6743, \mathrm{R}$ sq $=.3822$

On average we have about 30 observations per year. Eichholtz (1997) sums observations over two years to overcome difficulties with a low number of observations in individual years. We also present an index based on transaction in two-year periods. This shows a similar, if not smoother, picture of the development for both real and nominal house prices over our time period, see figure 5.

Figure 4. Dublin House Prices, 1709-1949, Time Dummy Hedonic, Nominal, Biennial

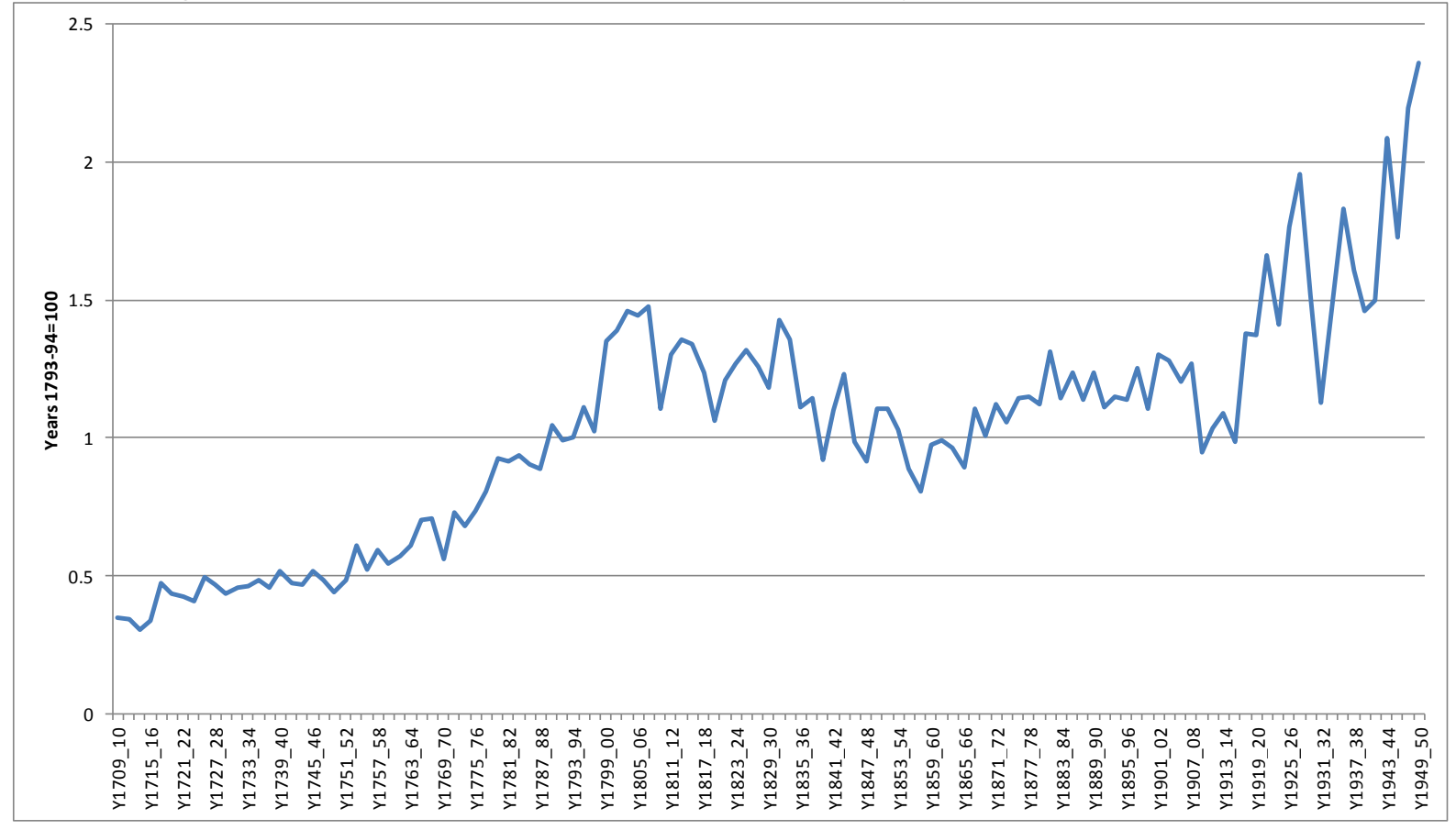

\footnotetext{
${ }^{4}$ Regression results are given in an Appendix.
} 
The limited nature of our data does present a number of issues - not least we do not have any control variable for dwelling size. Previous work has found this to be a key determinant of price (Conniffe and Duffy, 1999). One possible way of overcoming this deficit would be to use data on the number of rooms for each property from Census 1901. Alternatively, we examine the feasibility of constructed indices using the repeat sales methodology (Bailey, Muth and Nouse, 1963), a common approach in the literature constructing long run price indices.

We also examined the feasibility of constructing an index using this methodology. We found that a repeat sales index was not feasible using the current dataset for a number of reasons. It is recognised that the repeat sales approach does not use all the available data and is based on transactions. It was not possible to identify the house number for every dwelling in the dataset. House numbers were only used from 1780 onwards and only commonly used from 1800 on. Thus, some properties are not uniquely identifiable and so a repeat sale of such a property could not be identified. Furthermore, repeat sale indices are based on properties that transact more than once, further reducing the number of available transactions. Again, supplementing our data with information from the 1901 Census may allow us to address this issue in future work, but for the time being this remains a deficit in our analysis.

Notwithstanding this caveat, in looking at house prices it is also necessary to take account of the impact of inflation. We construct a long run series by linking Bank of England data from 1708 to 1973 with data on Irish inflation from the Society of Actuaries from 1608 and for more recent years from 1922 the Central Statistics Office, see Figure 5. Particularly for the early period price indices are dominated by food prices (Kennedy, 2002), which contributes to their volatility. For example, the spike around 1740 "is an unambiguous indicator of a massive attack on food supply, and hence the harbinger of famine" (Kennedy 2002). World War I also sees large increases in the price level and a similar effect is seen around the time of World War II. ${ }^{5}$

Figure 5. Inflation in Ireland, 1710-2014

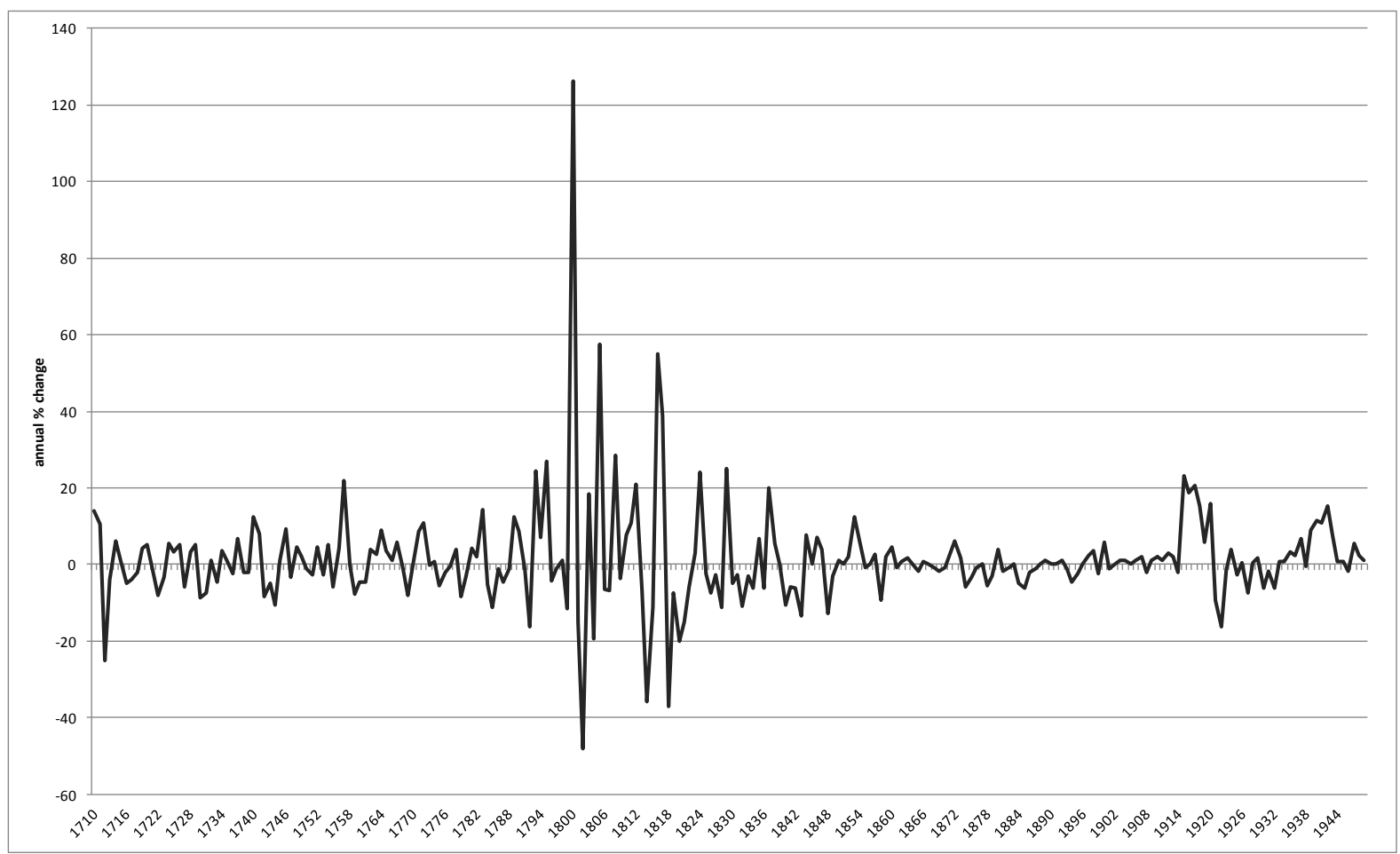

High inflation in the late 1790s and early 1800s resulted in house prices in real terms being much lower than the nominal prices previously observed, see Figure 6. However, the sharpest contrast is observed from approximately 1915. High inflation resulted in the path for real and nominal house prices diverging significantly. In nominal terms a house bought in 1916 would have risen by 142 per cent in value by 1949 . Real prices show a very different outcome, with house prices close to 24 per cent lower in 1949 compared with 1916.

${ }^{5}$ A detailed discussion of the cost of living in Ireland from 1698 to 1998 is contained in Kennedy 2002. 
Figure 6. Dublin House Prices, 1709-1949, Time Dummy Hedonic, Nominal and Real

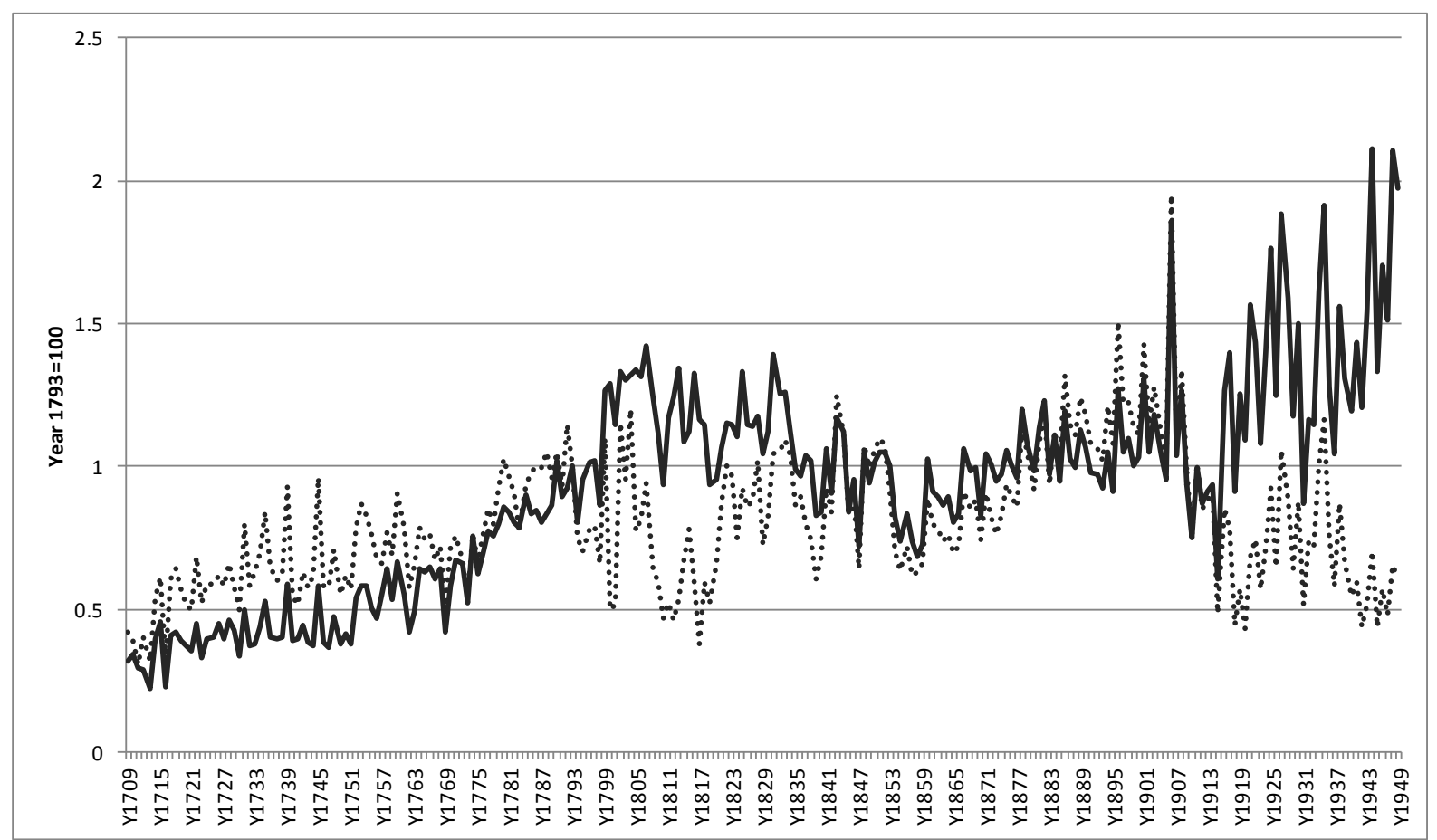

Note: Number of observations $=6743$. R sq=.2998

Given the changes that have occurred in Dublin over the centuries a key issue is how to deal with the evolution of the city. For example, Henrietta Street ${ }^{6}$ until the early 1800 's was a prosperous location. By 1900 it had become overcrowded and many of the buildings had become tenements. This remained the case until the 1940s when slum clearance began and streets were converted back to non-use, demolition or more reasonable tenancy. In addition a price index over such a long period should adjust to take account of the introduction of central heating, plumbing and running water, as well as electricity.

An associated issue is that of depreciation and any offsetting maintenance. Fishback and Kollmann (2012) show the impact of deprecation on US property values between 1920 and 1940. FitzGerald (2005) provides an estimate of annual depreciation of 0.6 per cent based on Census housing data from 1971 to 2002. Lyons (2015) applies a net depreciation rate of 1 per cent. Some of this depreciation will be offset by household expenditure on repairs and maintenance. Holmans (2005) in an overview of historical housing statistics for Britain argues that "it appears safe to conclude that only part of the long-term increase in house prices in real terms can be accounted for by quality improvements" However, we acknowledge that he lack of available data allowing us to take account of these developments means that our estimate of house price inflation is an over-estimate, with lower inflation expected if these quality adjustments are incorporated.

\section{RESULTS}

Our indices suggest a number of distinct phases in the evolution of Dublin nominal house prices. Although there is some volatility prices follow a general upward trend until post 1810 . This is then followed by a period of decline until the end of the 1850s, recovery until the early years of the 20th century. The overall trend is then upwards, with large increases in the subsequent period to 1949.

The House price index shows average nominal prices of $4.3 \%$ p.a. and average real prices of $4.5 \%$ p.a. over the period $1708-1949$. In the $18^{\text {th }}$ century nominal prices show a $4.5 \%$ p.a. increase while real prices only increase by $4.4 \%$ p.a. During the $19^{\text {th }}$ century nominal prices show a $1.3 \%$ p.a. increase while real prices increased by $3.2 \%$ p.a. From $1900-1949$ nominal prices increased by $9.8 \%$ p.a. while real prices increased by $7.4 \%$ p.a.

\footnotetext{
${ }^{6}$ We did document Henrietta Street for historical purposes but the low number of transactions and initial high prices were creating erratic data and for this reason we left it out of the main research.
} 
Table 1. Annual Growth Rates, Nominal and Real

\begin{tabular}{ccc}
\hline Years & Nominal & \multicolumn{2}{c}{ Real } \\
& Annual average change \\
& $\%$ & $\%$ \\
\hline $1708-1949$ & 4.3 & 4.5 \\
$1708-1799$ & 4.5 & 4.4 \\
$1800-1899$ & 1.3 & 3.2 \\
$1900-1949$ & 9.8 & 7.4 \\
\hline
\end{tabular}

\subsection{Dublin house prices in the $18^{\text {th }}$ century}

The early $18^{\text {th }}$ century is the earliest possible time to analyse Dublin house prices. Before then the majority of the estimated 2000 houses in Dublin were made of thatch and were of poor quality with very few surviving to this day. A change in building regulations resulting from the great London fire of 1666 and a large Dublin fire in 1660 ensured that brick and stone would be the building materials for the houses from that time on. The Dublin which exists today was planned and developed during the 18th century with some of the houses that were built at the time still in existence in modern times.

The $18^{\text {th }}$ century is a century of two very differing halves. Houghton (2008) summarises the $18^{\text {th }}$ century as a 'period of relative stagnation from 1700-1720', while the period 1720-1745 was a period of ' 25 years of crisis that included two famines'. In contrast, the latter period of the century and the early $19^{\text {th }}$ century, $1745-1815$, are described by Cullen (1972) as a 'long wave of sustained and relatively rapid economic growth., ${ }^{7}$

Looking at Dublin property prices in more detail they average $€ 240$ during the 1710 s and remarkably over the next forty years would barely move from this level. Prices reflect the improved economic situation of the 1730s with the average over the decade over $10 \%$ higher than the average from the 1720s. This was not sustained into the 1740 s with the average price falling to $€ 304$ over the decade.

Figure 7: Dublin House Prices, 1709-1799, Time Dummy Hedonic, Nominal and Real

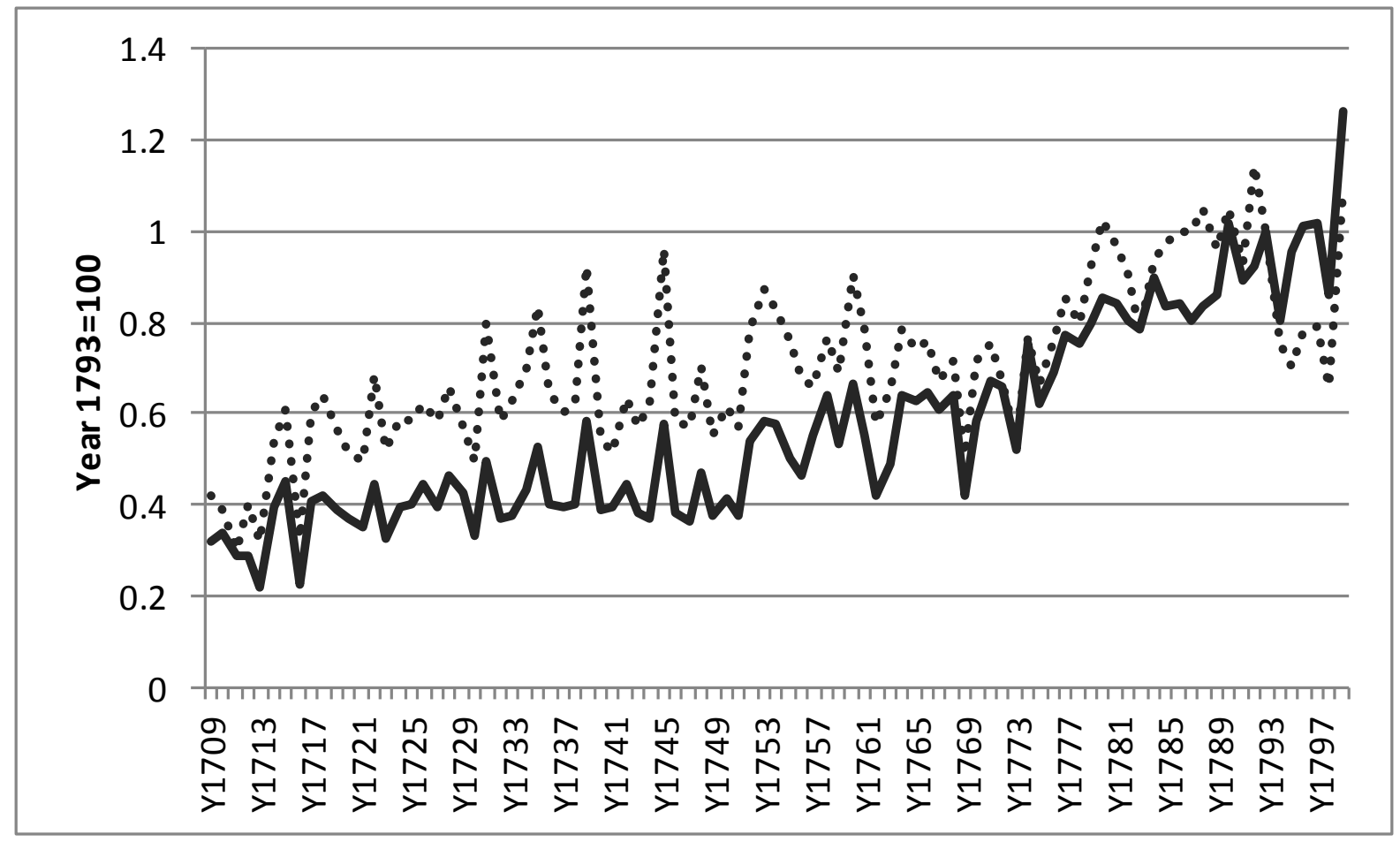

\footnotetext{
${ }^{7}$ Houghton (2008), p.4.
} 
Property prices remained flat throughout the rest of the 1740s, with the exception of 1745 and by 1751 had barely moved from levels back in the early 1720 s. Average prices rose to a new high of $€ 509$ in 1759 , a large increase of the lows at the beginning of the decade. The "economic miracle" described by Cullen ${ }^{8}$ continues in the 1760 s with the Dublin prices averaging $€ 438$. The mixed economic fortunes of the 1770 s are reflected in Dublin house prices, with a steady start to the decade but a considerable fall in prices for 1773 . The average price for the decade was $€ 552$, a very large rise on the 1760s. The improved economic conditions led to new levels of property prices with prices hitting over $€ 700$ by 1782 . Dublin house prices continued upward during the 1790 s with the exception of 1798 perhaps due to the rebellion of that year and Cullen does refer to a 'sharp recession in investment in 1797 and 1798.'9

\subsection{Dublin house prices in the $19^{\text {th }}$ century}

The $19^{\text {th }}$ century does not follow the previous century trend of increasing prices. Three of the decades show negative growth with the famine decade from 1844-1853 showing negative annual growth rates of $-3.1 \%$ in nominal and $-3.5 \%$ in real terms. The 1800 s continued the upward trend with an average price of $€ 966$. The Napoleonic War boom had pushed property prices to new levels peaking in 1804 at a level approximately 50 per cent higher than the pre boom levels of 1780. Certainly our analysis shows property prices continuing to increase the whole way through the decade, however there is a fall-off in prices towards the end of the decade (1808-1811).

The Act of Union was passed in 1800 which abolished the Irish parliament making London the location where MPs and their families, servants etc. would relocate to. There was much debate about the effect this relocation could have on the Dublin housing market with some fearing the impact of so much influence away from Dublin. O'Grada (1994) argues that 'the economic input of the Union in the short run was minor with manufacturing output and trade continuing to grow' ${ }^{10}$ In a contrasting view, Killeen (2011) suggests that 'Dublin went into steep decline after the union' but qualifies this statement by saying that 'this did not happen all at once .....but progressively over time.' ${ }^{11}$ The 1810s are seen as a mixed decade split by the end of the Napoleonic Wars in 1815. Cullen (1972) outlines that 'prices fell sharply from their inflated level, and the trend was now downward. ${ }^{12}$

Figure 8: Dublin House Prices, 1800-1899, Time Dummy Hedonic, Nominal and Real

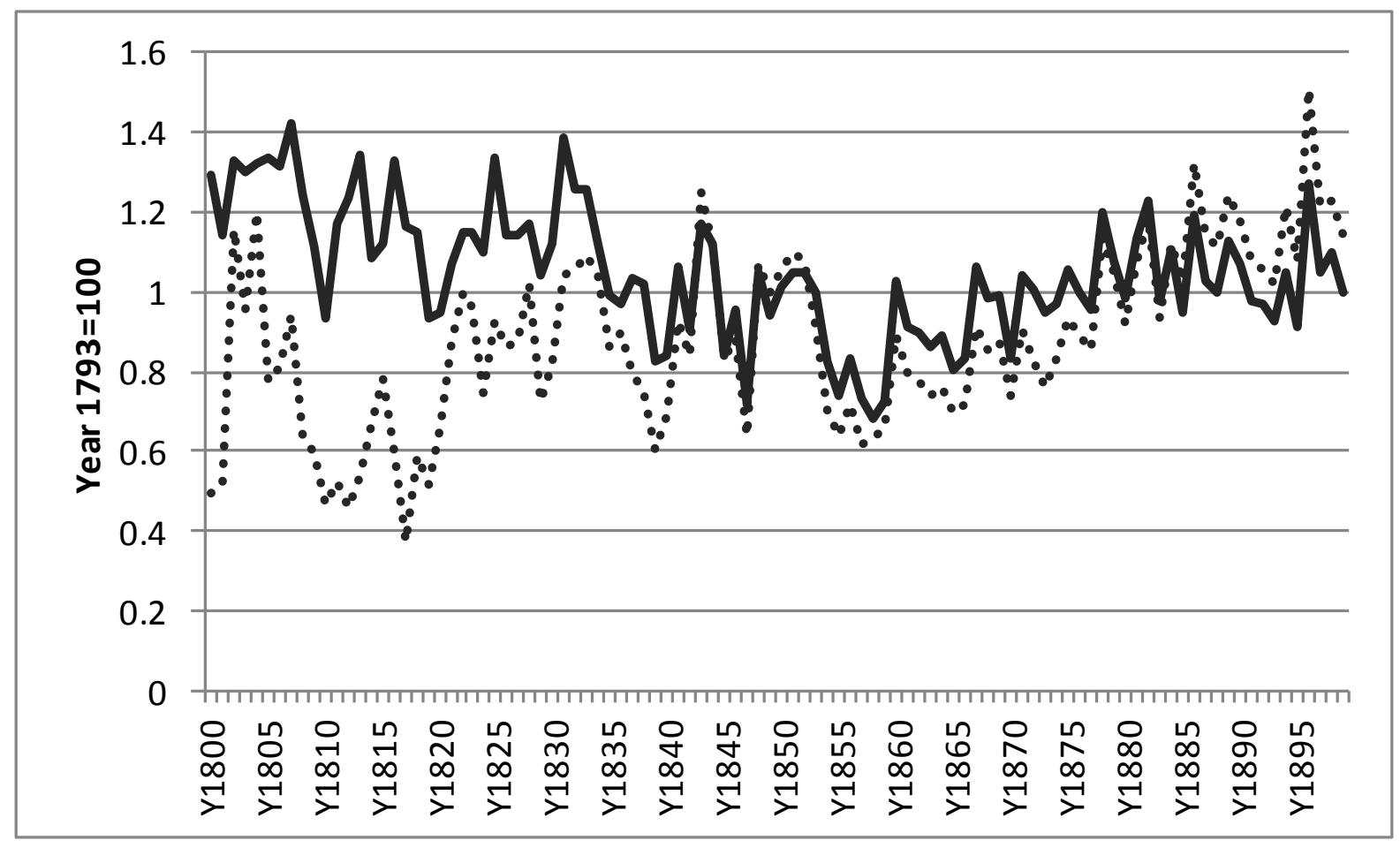

\footnotetext{
${ }^{8}$ Cullen (1986), p.184.

${ }^{9}$ Cullen (1972), p.100.

${ }^{10}$ O’Grada (1994), p.46.

${ }^{11}$ Killeen (2011), p.113.

${ }^{12}$ Cullen (1972), p.101.
} 
The 1810s are a mixed decade split by the end of the Napoleonic Wars in 1815. This could be a combination of a delayed effect from the Act of Union and also the end of the war boom years from 1793-1815. In particular, Dublin house prices show steep falls during 1819 and 1820.

Economic performance in the early part of the 1820 s was affected by famine and post war recession. These trends are mirrored in our house price analysis. There are high prices from 1831-1834 but this is followed by a fall-off towards the end of the decade. Unsurprisingly, there is steep fall in property prices during the famine decade of the $1844-1853$ where nominal prices fell by $3.1 \%$ p.a. and real prices fell by $3.5 \%$. Dublin property prices had fallen to levels not seen since the pre-boom 1790 s.

O'Rourke and Pollak (1991) detail the volume of property transactions in Ireland on an annual basis between 1708 and 1988. The volume of transactions fell sharply in 1842 and remained low for the rest of the decade. ${ }^{13}$ Dublin property prices showed some recovery in the first part of the 1850 s but the property prices fell away in the second half of the decade. The 1860s was also a mixed decade with a fall in the middle of the decade but a strong increase by 1868 . This increase was the start of a twenty year period that would see property prices recover to pre-famine levels.

Despite a poor economic environment, Dublin house prices increased slightly over the 1880s, although prices fall towards the end of the decade. Dublin property prices had increased by over 20 per cent from the lows of the 1850s. Although the 1890 s saw an improvement in economic and social conditions ${ }^{14}$ Dublin property prices show a mixed decade with low prices in the first half of the decade but large increases towards the end of the decade.

Cullen (1972) refers to the "static nature of rents in the 19th century", claiming that "rents did not alter much after 1815 ". Our measure of Dublin property prices seems to back up this finding as property prices stayed remarkably static throughout this period as well.

One interesting part of this period was the Encumbered Estates Court which was the NAMA (National Asset Management Agency) equivalent of the time dealing with insolvent estates. The Great Famine of 1845-1849 decimated the Irish economy of the time. Cullen ${ }^{15}$ outlines that there was a $45 \%$ decline in employment between the 1840 s and 1870 s and that by 1847 roughly $40 \%$ of the population was being fed at soup kitchens. Hundreds of thousands of people died and emigrated leaving many Irish estates in huge debt due to falling land and rental values. The Encumbered Estates Acts of 1848 and 1849 established a method of selling off these insolvent estates and paying off its creditors.

For example in 1852, the Encumbered Estates Court disposed of seven properties in Capel Street for $£ 1460$ while in the same year three properties in Stephens Green were disposed of for $£ 1780$. In some cases large profits were made quickly with a James McFadden obtaining a house in Stephens Green from the court for $£ 670$ in 1857 and selling the property in 1859 for $£ 820$. A criticism of the Encumbered Estates is that it had sold multiple properties to foreign speculators. However it appears from our research that most of the purchasers of Dublin properties under the Act were already Dublin residents rather than English speculators and most of the transactions were for single properties.

\subsection{Dublin house prices in the $20^{\text {th }}$ century}

The first half of the $20^{\text {th }}$ century shows larger increases in house prices than the previous 200 years much of which is inflation related. The 1910 s show an annual increase of $14 \%$ in nominal terms but only $4.9 \%$ in real terms, while the 1940 s show an increase of $7.5 \%$ in nominal terms but only $2.9 \%$ in real terms.

The $20^{\text {th }}$ century shows very little movement for the first two decades but the post-World War 1, inflation brings nominal values to new heights. The first decade of the new century is seen as a good decade and the average for Dublin prices reaches a level above the average for the decade beginning in 1810. This suggests that it took ninety years for property prices in Dublin to reach the average price levels of the early $18^{\text {th }}$ century, showing how difficult economically the $19^{\text {th }}$ century was for Ireland. Property prices average over $€ 1000$ during the latter half of the 1910 s showing the power of the post war inflation. The increase in nominal prices of $64 \%$ from an average of $€ 825$ in the 1910 s to a new level of $€ 1291$ in the 1920 s is the largest increase in values over a single decade in our study.

\footnotetext{
${ }^{13}$ O’Rourke \& Polak, (1991)

${ }^{14}$ Cullen (1972), p150.

${ }^{15}$ Cullen (1972), p132.
} 
Cullen quotes one merchant of the time as saying 'the years 1915 to 1921 were really legendary' ${ }^{16}$, while O'Grada reports that 'money grew on the top of bushes'. The economic boom is also reflected in our measure of Dublin house prices. There is a debate about how well the economy did during the 1920s. The 1920s see property prices continuing their increases, again due to the high inflation levels of this time. However, O'Rourke states that 'the Irish economy grew sluggishly during the 1920's with high emigration and living standards barely rose'. ${ }^{17}$ This contrasts with our results for Dublin house prices over the period, perhaps due to an urban rural economic divide at the time.

In contrast, the 1930s were a difficult decade and this is reflected in property prices with our index showing average prices falling to an average of $€ 1229$. The 1940s is generally seen as a mixed decade with a difficult start to the decade followed by a post-World War II recovery. Again house prices follow this pattern with our index showing an average of $€ 1460$. O'Rourke states that 'In 1945, Ireland remained one of the poorest countries in Western Europe but experienced a post war recovery, like the rest of Europe. ${ }^{18}$ Houghton also supports the idea of the post war recovery stating 'the war was followed by a rebound and per capita real GDP rose by 4.1\% p.a. between 1944 and $1950 \ldots .$. and unemployment fell from $15 \%$ in 1940 to just over $10 \%$ in 1945 . $^{19}$

The best performing time in terms of nominal prices is the second half of the 18th century when nominal prices increased by $89 \%$ but in real terms the increase was only $6 \%$ over the same period. In real terms the best performing period was the second half of the 19th century where there was an increase of $107 \%$ compared with a $25 \%$ nominal increase. The worst performance in nominal terms was the first half of 19th century where property prices fell by $21 \%$ due to the famine decades of the 1820 s and 1840 s. Interestingly real property prices rose during this period by $19 \%$.

The widest divergence between nominal and real prices occurs the during the first half of the 20th century where a purchaser of a property for $€ 1000$ in 1900 could have sold the same property for $€ 1520$ by 1949, not realising that in real terms the property had lost $50 \%$ of its value due to the high inflation levels of the time.

Figure 9: Dublin House Prices, 1709-1949, Time Dummy Hedonic, Nominal and Real, Biennial

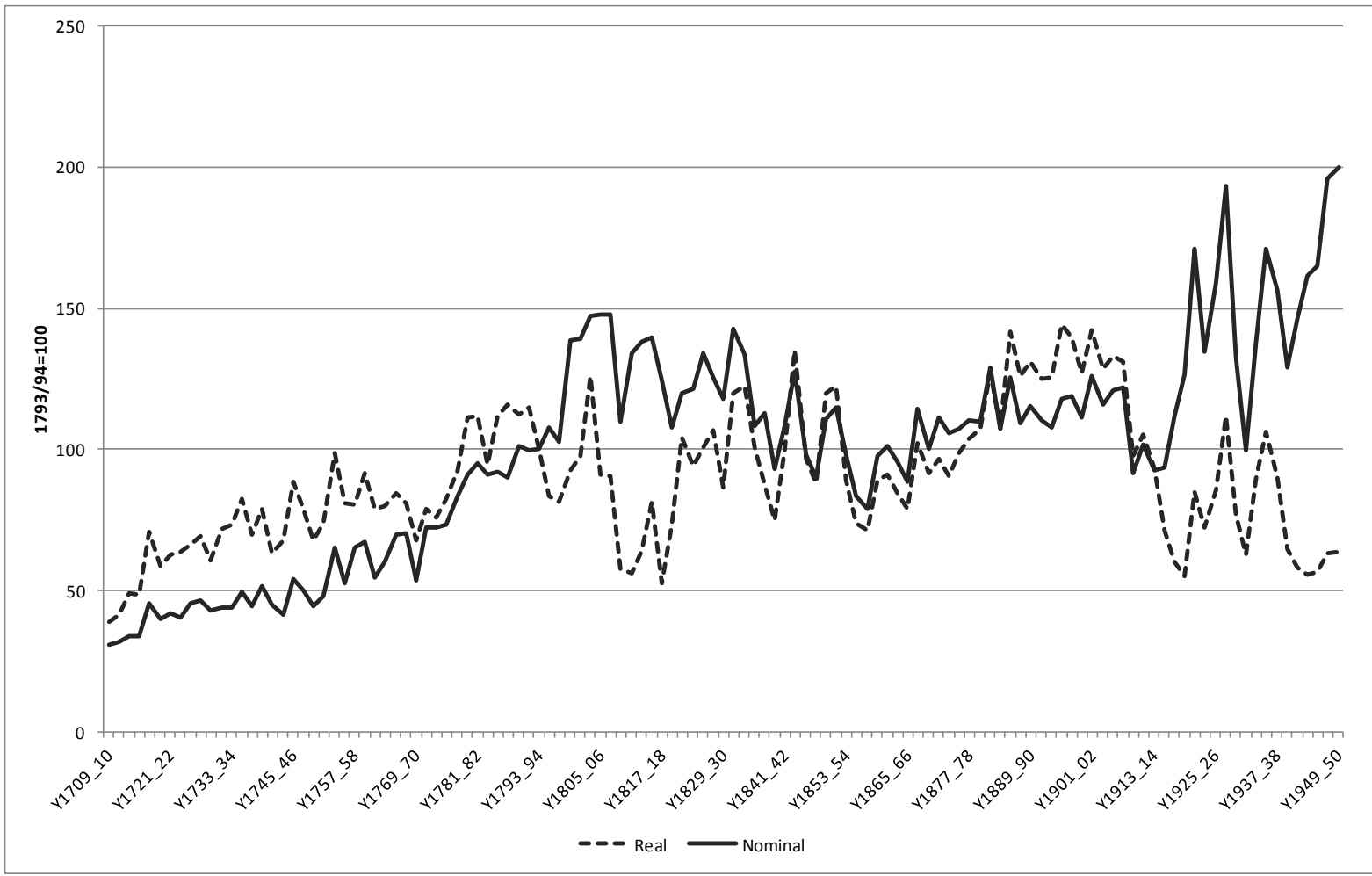

${ }^{16}$ Cullen (1972), p169.

${ }^{17}$ O’Rourke \& Polak, (1991)

${ }^{18}$ O'Rourke (1991), p14.

${ }^{19}$ Houghton (2008), p12. 


\section{CONCLUSION}

In this paper, a long run index of Dublin property prices from 1708-1949 is presented using transactions recorded in the Registry of Deeds. Combining with a long run Irish inflation series the index is presented in both nominal and real terms. To overcome the difficulty of low observations in a given year the index is biennial. A Repeat Sales index was not possible using the current dataset due to due to difficulties in identifying house numbers in the $1700 \mathrm{~s}$.

In nominal terms, property prices increased more than 6 times over the duration of the index but only by 1.5 times in real terms, while the nominal annual compound rate was 0.725 . Nominal property prices appear to be procyclical and follow the general state of the Irish economy. When the economy was performing well during the late $18^{\text {th }}$ century and the early $20^{\text {th }}$ century nominal property prices rose significantly. During the difficult $19^{\text {th }}$ century in Ireland, property prices fell in the first half of the century and took almost a century to reach their previous levels. In real terms, property prices fell by 50\% from 1900-1949 due to the very high levels of general price inflation.

The results would appear to be consistent with similar studies in other countries showing that large increases in property values are a recent phenomenon. The importance of property to the wider economy has been demonstrated dramatically in Ireland in recent times. This historical index should benefit our understanding of how property values follow the general fluctuations in the wider Irish economy. Our next step is to fill the gap of 1950-1969 between our index and the CSO index which begins in 1970. Work on this has begun and will be presented shortly.

\section{References}

Brady, J. and A. Simms (2001), Dublin through Space and Time, Four Courts Press.

Bohlin, J (2014), 'A price index for residential property in Göteborg, 1875-2010', in Edvinsson, R, T Jacobson, and D Waldenström (eds.), Historical Monetary and Financial Statistics for Sweden, volume 2: House Prices, Stock Returns, National Accounts and the Riksbank Balance Sheet, 1620-2012, Sveriges Riksbank and Ekerlids förlag, Stockholm.

Conniffe, D. and D. Duffy, (1999) "Irish House Price Indices: Methodological Issues" Economic and Social Review, Vol.30, No.4, October.

Cullen, L.M., (1972) An economic history of Ireland since 1660, B.T. Batsford Ltd.

Dickson, D., (2014) Dublin, The making of a capital city, Profile Books Ltd.

Eichholtz, P (1997), 'A Long Run House Price Index: The Herengracht Index, 1628-1973', in Real Estate Economics, Vol. 25, pp. 175-192.

Eitrheim, Ø, and S Erlandsen (2004), 'House Price Indices for Norway 1819-2003', in Eitrheim, Ø, J T Klovland and J F Qvigstad (eds.), Historical Monetary Statistics for Norway, Norges Bank, Oslo.

Eurostat, 2013, Handbook on residential Property Price Indices (RPPIs), Eurostat Methodologies and Working Papers, 2013 edition.

Fishback, P.V., and T. Kollmann, 2012, 'New multi-city estimates of the changes in home values, 1920-1940', NBER Working paper 18272, August.

FitzGerald, J. (2005) ,The Irish Housing Stock: Growth in Number of Vacant Dwellings'. Special Article in McCoy, D., David, D., Bergin, A., Garrett, S., and Y. McCarthy. ESRI Quarterly Economic Commentary, Spring. Dublin: Economic and Social Research Institute

Foster, R., Modern Ireland 1600-1972, London.

Harrison, Fred (2010) Boom Bust- House prices, banking and the depression of 2010. 
Holmans, A., (2005), Historical Statistics of Housing in Britain, Cambridge Centre for Housing and Planning Research.

Jones, O., (2001), Capel Street, a study of the past, A vision for the future, Dublin Civic trust.

Killeen, R., (2011) Historical Atlas of Dublin, Gill and Macmillan.

Knoll, K., and M. Schularick and T. Steger, 2014, No Price Like Home: Global House Prices, 1870-2012, Centre for Economic Policy research Discussion Paper No. 10166, September.

Lyons, R., (2015), A housing price index for Dublin, 1900-2015, Central Bank of Ireland Economic History Conference, June 2015.

McCullogh, Niall, (2007), Dublin, An Urban History, Anne Street Press.

Monnery, N., (2011), Safe as houses? A Historical Analysis of Property Prices, London Publishing Partnership.

Murphy, A., 1998, 'Econometric Modelling of the Irish Housing Market' in Bacon et al An Economic Assessment of Recent House Price Developments, Dublin, Stationery Office, April,

Nevin, S., (2012), 'History Repeating: Georgian Ireland's Property Bubble', History Ireland.

Nugent, B., (2012), A guide to the 18th century land records in the Irish registry of deeds, Corstown

O’Grada,C., (1994), Ireland, A new economic history 1780-1939, Clarendon Press.

O'Hagan, J., and C. Newman, (2008), The economy of Ireland, national and sectoral Policy issues, Tenth Edition, Gill \& Macmillan.

O’Hanlon, N., 2011, “Constructing a National House Price Index for Ireland, Journal of the Statistical and Social Inquiry Society of Ireland, Vol. XL

O’Rourke, K., (1994), Emigration and living standards in Ireland since the Famine, UCD School of economics.

O’Rourke, K., and B. Polak, (1991), Property transactions in Ireland, 1708-1988; an introduction, UCD School of economics.

Söderberg, J, S Blöndal, and R Edvinsson (2014), 'A price index for residential property in Stockholm, 18752012', in Edvinsson, R, T Jacobson, and D Waldenström (eds.), Historical Monetary and Financial Statistics for Sweden, volume 2: House Prices, Stock Returns, National Accounts, and the Riksbank Balance Sheet 16202012, Sveriges Riksbank and Ekerlids förlag, Stockholm. 
APPENDIX: Model 1. Dublin House Prices, 1709-1949, Time Dummy Hedonic, Nominal

\begin{tabular}{|c|c|c|}
\hline \multicolumn{3}{|l|}{ Parameter Estimates } \\
\hline Variable & \multirow{2}{*}{$\begin{array}{l}\text { Parameter } \\
\text { Estimate }\end{array}$} & \multirow[b]{2}{*}{$\operatorname{Pr}>|t|$} \\
\hline & & \\
\hline Intercept & 6.59122 & $<.0001$ \\
\hline \multicolumn{3}{|l|}{ Location } \\
\hline \multicolumn{3}{|l|}{$($ Ref $=$ St. Stephen's Green) } \\
\hline AnneSt & -0.42296 & $<.0001$ \\
\hline Britainst & -0.40833 & $<.0001$ \\
\hline BachelorsW & -0.14271 & 0.0001 \\
\hline Capelst & -0.28377 & $<.0001$ \\
\hline GeorgesS & -0.13087 & $<.0001$ \\
\hline MeathSt & -0.73175 & $<.0001$ \\
\hline MerchantsQ & -0.36139 & $<.0001$ \\
\hline PatrickSt & -0.63741 & $<.0001$ \\
\hline UshersQ & -0.31344 & $<.0001$ \\
\hline \multicolumn{3}{|l|}{ Number of properties } \\
\hline \multicolumn{3}{|l|}{ (Ref=One dwelling) } \\
\hline Less than one dwelling & -1.09805 & $<.0001$ \\
\hline Two dwellings & 0.24568 & $<.0001$ \\
\hline Three dwellings & 0.48164 & $<.0001$ \\
\hline Four dwellings & 0.77601 & $<.0001$ \\
\hline More than five dwellings & 0.6816 & $<.0001$ \\
\hline \multicolumn{3}{|l|}{ Transaction Type } \\
\hline \multicolumn{3}{|l|}{$($ Ref $=$ rental $)$} \\
\hline Sale & -0.28771 & $<.0001$ \\
\hline Assignment & 0.47603 & $<.0001$ \\
\hline \multicolumn{3}{|l|}{ Property type } \\
\hline \multicolumn{3}{|l|}{$($ Ref $=$ House $)$} \\
\hline House and some commercial & 0.06253 & 0.0027 \\
\hline Commercial & 0.23205 & $<.0001$ \\
\hline Garage & 0.14932 & 0.0386 \\
\hline Garden & -0.04916 & 0.107 \\
\hline Year Dummy Variables & Not reported & \\
\hline Adj R-Sq & 0.3822 & \\
\hline
\end{tabular}




\section{FIRST VOTE OF THANKS PROPOSED BY RONAN LYONS}

I would like to thank the authors and their research assistants for completing a mammoth project of immense public good. Their paper on the price of real estate in Dublin over the period from 1708 to 1949 is another step in the cliometric revolution taking place in Ireland.

I have some methodological comments and then some broader thoughts on how to interpret the work and what research might come next. Methodologically, one concern about the dataset as built is that it covers properties whose use changed substantially over the period, which thus may have affected the value. It is perhaps more accurate to think of this as capturing the value of real estate, rather than 'house prices' per se (as included in the title). Secondly, due to the nature of the Irish legal system, it would be useful to distinguish - even if only in robustness checks - between first leases and assignments, as there is something of a grey line between owning and renting for the period covered. Thirdly, I think it would be useful to exclude deeds with multiple units transacted, rather than include that as a control; again, this could be a robustness check.

I do think there is some potential for a quasi-repeat sales index in this dataset, given the chain-linked nature of leases reciting previous leases, although perhaps this is a target for a bigger project when more records are digitized. Thirty observations per year is actually not that far off much of the existing literature in this regard, so the authors should not feel that this is a significant limitation.

In terms of putting their results in context, it would be worth comparing their results not only to existing estimates for Dublin (Lyons 2015) but also other works (including Eichholtz for Amsterdam and a more recent summary paper by Knoll and co-authors that looks across a number of countries). In addition, distinguishing between real and nominal changes might yield some interesting insights, for example about the nature of property as a hedge against inflation - particularly in some periods. A final comment on the presentation of findings is that I think depreciation is an important additional factor to bear in mind: as per Lyons (2015), the inclusion of depreciation and maintenance can actually overturn headline findings about the performance of an asset's price over time.

More broadly, the information gathered here can act as a launch-pad for numerous further studies. An obvious one, linked to the first point above about change of use, is social history and how and why these streets changed over time. Prices captured here are the intersection of supply and demand and, if broader macroeconomic conditions drive demand, what account should be made of supply-side factors? Finally, there are some interesting specific hypotheses that could be tested, given what happened in the Irish economy in the period covered. An example that springs to mind is 'catastrophic agglomeration', both after the Act of Union when MPs/Peers and top-level civil servants left for London and potentially again during the War of Independence.

\section{SECOND VOTE OF THANKS PROPOSED BY JOHN FITZGERALD}

I would like to congratulate the authors on what I know is a 'magnum opus'. Forty five years ago I spent approximately a year in the Registry of Deeds going through the ledgers which recorded all deeds since the early $17^{\text {th }}$ century. My mission was to understand the development of the economy of Drogheda in the late $18^{\text {th }}$ century. In the case of this paper they span an amazing two and a half centuries and their work reflects a massive input of research time.

We economists have become used to online data. By contrast, the task of actually collecting the data for research observation by observation in such a "panful" manner is so daunting that economists are normally unwilling to undertake a task like this paper. It is not just the members of this Society that should be grateful to the authors but also all those interested in Irish economic history.

The paper describes the trends in house prices in Dublin between 1700 and 1949 in both nominal and real terms. In looking at fifty year periods they show how the behaviour of house prices has varied greatly. This tells us much about the underlying pattern of economic growth but it also invites further research - maybe the authors' next paper!

I have a number of comments on the paper which may add to the background information available in the paper. I also have some suggestions on how this valuable data set could be further exploited in further papers. First a few minor points. The Griffith Valuation of the 1860s and an earlier valuation of the 1830s gives detailed information on all houses which could be used to benchmark house sizes. The 1860s valuation was only changed where there was a new build - this would show when individual properties were rebuilt. 
Honohan (2002) shows that, while the Irish pound had a fixed value relative to sterling over most of the period between 1803 and 1821 the value of the currency fluctuated relative to sterling, deviating from the published rate. ${ }^{1}$

An article by Charles Meenan in Studies looked at the movement of the professional classes from the north side of the city in the early $19^{\text {th }}$ century to the south side in the $20^{\text {th }}$ century. This change will have affected the relative valuations of some of the streets within the sample.

Do the authors know the nature of the tenants or owners of the houses over time? The contemporary directories (Thoms and Pettigrew and Oulton) from the beginning of the $19^{\text {th }}$ century ${ }^{2}$ give a lot of information, as does the 1901 and 1911 census. A change in the status of the occupiers, if it could be quantified, could be an interesting factor in helping explain price developments.

Factors that may have affected house prices might be tested in a further paper using the data. One concerns that the data are for a series of houses in streets in what is now the centre of a city with a population of over a million. Over the $19^{\text {th }}$ and $20^{\text {th }}$ centuries the city grew substantially, though at an uneven rate (Table 1). The pattern of development was significantly affected by the development of horse-drawn trams and the railways in the second half of the $19^{\text {th }}$ century and by the wider availability of public transport and cars in the $20^{\text {th }}$ century. These developments made it possible for the city to grow by spreading out. Previously, for the vast bulk of citizens the size of the city was determined by how far one could walk.

Table 1. Population of Dublin

$\begin{array}{llll}1821 & 186 & & 186 \\ 1841 & 239 & & 239 \\ 1871 & 246 & 57 & 303 \\ 1901 & 291 & 75 & 366 \\ 1926 & 317 & 98 & 415 \\ 1951 & 572 & 48 & 620\end{array}$

Note that for 1951 Pembroke and Rathmines, which were previously considered suburban are incorporated into the city.

Thus the development of the suburbs from the mid $-19^{\text {th }}$ century onwards will, to some extent, have eased pressure on the housing in the city centre. It could be useful to test whether the population of Dublin affected the price of houses and whether the growth of the suburbs, as opposed to the city, eased pressures.

A second factor which could have affected the pressure on house prices will be emigration. Data are available on emigration by year for the Republic back to 1864 and for Ireland back to 1831. While the data suffer from some problems in the pre-independence period, nonetheless they would be a useful indicator of domestic labour market conditions. These data could be tested whether they helped explain house prices.

The CSO continued to publish the CPI to the base 1914=100 until the last decade. This could be used to take consumer prices back to 1914 . Obviously for the earlier period reliance has to be had on the GB price series ${ }^{3}$. By linking UK consumer price indices, albeit of indifferent quality, to the Irish index in 1914 it would be possible to produce a price index reflecting consumer prices for most of the period. This series might well show a different pattern than that for agricultural prices and better reflect the standard of living of urban dwellers in Ireland.

Agricultural price indices are available between 1766 and 1900 from Kennedy and Solar, 2007. ${ }^{4}$ Series from the late $19^{\text {th }}$ century are available from the CSO. Thus a continuous series on agricultural prices is available for most of the period. As agricultural prices would have affected rental income of landlords, some of whom would have been resident in the city, these prices might help explain the behaviour of house prices in Dublin - reflecting income rather than consumer prices. Using the two price series (consumer and producer) would bring additional information.

\footnotetext{
${ }^{1}$ Honohan, P., 2002, 'Using Other People's Money: Farewell to the Irish Pound', History Ireland, Vol. 10, No. 1 Spring, pp. 34-37.

${ }^{2}$ There is one for Drogheda in the 1770 s so there may be others for Dublin in the $18^{\text {th }}$ century.

${ }^{3}$ Mitchell, B, 1994, British Historical Statistics, Cambridge: Cambridge University Press.

${ }^{4}$ Kennedy, Liam and Peter M. Solar. 2007, Irish agriculture : a price history, from the mid-eighteenth century to the eve of the First World War Dublin: The Royal Irish Academy
} 
With these variables it might be possible to model the behaviour of house prices as a function of consumer prices, agricultural prices (reflecting landlords' incomes), demographics and the labour market. An additional dummy might be included if it is known that a deed was a mortgage. The mortgage will normally be correlated with the value of the property but be for a sum less than the value for the collateral.

As well as economic shocks, such as the famine, there were two Brexit type shocks over the two and a half centuries: The act of Union and Independence. The act of Unions does not appear to have had an immediate effect on prices. However, the ending of the Napoleonic wars in 1815 combined with a collapse in agricultural price may have triggered a delayed effects. Many aristocratic families moved their urban base to London. There also may have been effects on the number of local (well paid) administrators.

In the case of independence in 1922 it appears that there was a major outflow of people around that date. ${ }^{5}$ It would appear that many of them were Protestants and the outflow may have disproportionately affected the Dublin region. Does this shock show up in the house price data?

In the $19^{\text {th }}$ century and up to the second half of the $20^{\text {th }}$ century renting was a much more common form of tenure than it is today among middle class and wealthy households. The terms of the leases were not such as to appear in the Registry of Deeds. However, it is an interesting question why this was the case in contrast to today. With limited prospect of capital gain and slow growth in population renting may have made more sense than today. Would it be possible to consider the user cost of housing for renters and owners over the period 1700-1949. It might help explain patterns of change in house prices and difference in tenure behaviour.

\section{DISCUSSION}

Seán Lyons: The hedonic regression used to construct the index seems to have fixed effects for the "quality" controls, such as the presence of a garden or the various transaction types. This means that the proportional effect of each characteristic on prices is assumed to be constant over the whole sample period. Did you consider testing whether these coefficients are constant over time, for example by introducing dummy variables for decades and interacting them with the characteristic variables?

\footnotetext{
${ }^{5}$ FitzGerald, J, 2016, "A Hundred and Fifty Years of Vital Statistics: Documenting Demographic Change in Ireland", Journal of the Statistical and Social Inquiry Society of Ireland, forthcoming.
} 